Ewa Cherner

https://orcid.org/oooo-0002-5978-4984

Paryż

Kazimierz Bem

https://orcid.org/oooo-oooI-9I28-8924

Ewangelikalna Wyższa Szkoła Teologiczna (Wrocław)

Marlborough

\title{
Przyczynek do dziejów zborów ewangelicko- -reformowanych w Piaskach Luterskich (Wielkich) koło Lublina i Tursku Wielkim oraz kontaktów między Jednotami Małopolską i Litewską na przełomie XVIII i XIX wieku
}

Niniejszy artykuł przedstawia nieznane dotychczas listy dotyczące obsadzenia zboru w Tursku Wielkim i ks. Jana Herowskiego (z 1798 i 1799 r.), a także zboru ewangelicko-reformowanego w Piaskach Luterskich (Wielkich) z 1806 r. oraz dwóch pastorów z nim związanych: Adama Huissona i Józefa Kühna. Korygują one i uzupełniają wiedzę o obu zborach i wspomnianych wyżej duchownych oraz ukazują kontakty między kalwińskimi Jednotami Małopolską i Litewską na przełomie XVIII i XIX w.

The article presents unknown letters concerning the filling of pastoral vacancy at Tursko Wielkie written by Rev. Jan Herowski (from 1798 and 1799), and the letters about the Evangelical Reformed Congregation at Piaski Luterskie (Wielkie) from 1806 by two pastors associated with it: Adam Huisson and Józef Kühn. The letters correct and complement our knowledge about the two congregations and the pastors mentioned above as well as reveal contacts between the Calvinist Unities (Churches) of Lesser Poland and of Lithuania at the turn of the nineteenth century. 
Słow a klucz ow e: kalwinizm w Małopolsce, kalwinizm na Litwie, kler kalwiński

Ke yw o r d s: Calvinism in Lesser Poland, Calvinism in Lithuania, Reformed Clergy

W zespole Synod Kościoła Ewangelicko-Reformowanego przechowywanym w Bibliotece im. Wróblewskich Litewskiej Akademii Nauk w Wilnie (Lietuvos mokslų akademijos Vrublevskių biblioteka) znajdują się trzy listy Jednoty Małopolskiej adresowane do synodu Jednoty Litewskiej. W tym samym zespole znajduje się osobisty list jednego z duchownych Jednoty Litewskiej do patronki, dotyczący jego nieudanej wokacji do Małopolski. Są one interesującym przyczynkiem do dziejów parafii ewangelicko-reformowanych w Piaskach Luterskich (Wielkich) i Tursku Wielkim, a także stosunków pomiędzy Jednotami Małopolską i Litewską na przełomie XVIII i XIX w. Pozwalają również uściślić i skorygować niektóre informacje podane dwadzieścia lat temu w publikacji na temat zboru w Piaskach Luterskich (Wielkich) oraz uzupełnić materiały o tymże zborze znajdujące się w Bibliotece Uniwersyteckiej w Warszawie, w zespole Synod Ewangelicko-Reformowany pod sygnaturą $600^{1}$.

Zachowany w Wilnie zespół o sygnaturze F40-190 to niewielka teczka zawierająca zaledwie 37 kart dokumentów dotyczących parafii ewangelicko-reformowanej Jednoty Małopolskiej w Piaskach Luterskich (Wielkich) k. Lublina. Większość tekstów powstała w latach 1723-1725 i odnosi się do procesu wytoczonego w 1724 r. patronowi zboru Bogusławowi Aleksandrowi Suchodolskiemu (1686-1741) przez katolickiego plebana piaseckiego ks. Izdebskiego z powodu remontu miejscowego kościoła ewangelicko-reformowanego (kalwińskiego). Proces ten, zagrażający nie tylko istnieniu zboru w Piaskach, ale też stwarzający niebezpieczeństwo unicestwienia kalwinizmu w Lubelskiem, odbił się szerokim echem w ewangelickim środowisku Korony i Wielkiego Księstwa Litewskiego. W obronę zboru, także materialnie, zaangażowali się krewni żony patrona zboru, Ludwiki ze Stryjeńskich Suchodolskiej (zm. 1755), która pochodziła z Wielkiego Księstwa Litewskiego: Stryjeńscy, Grużewscy etc. ${ }^{2}$

${ }^{1}$ K. Bem, Zarys dziejów zboru ewangelicko-reformowanego w Piaskach Luterskich (Wielkich) koto Lublina: 1563-1649-1849, OiRwP, 43, 1999, s. 85-98; W. Kłaczewski, Zbory różnowiercze w Piaskach i ich patronowie, „Rocznik Lubelski”, 21, 1979, s. 65-75.

2 W. Kriegseisen, Ewangelicy polscy i litewscy w epoce saskiej (1696-1763). Sytuacja prawa, organizacja i stosunki międzywyznaniowe, Warszawa 1996, s. 128. 
We wspomnianej teczce znajdują się również dokumenty dotyczące spraw duszpastersko-kadrowych małopolskich parafii. Dwa listy, z 1795 i 1798 r., to prośby o skierowanie przez Jednotę Wielkiego Księstwa Litewskiego duchownych do pracy w Piaskach. W odpowiedzi na pierwszy list synod litewski przychylił się do prośby i wytypował do pracy duszpasterskiej w Małopolsce ks. Samuela Nerlicha (1765-1843), który zadeklarował chęć przyjęcia wokacji. Z niejasnych przyczyn do jego wyjazdu z Litwy nigdy nie doszło ${ }^{3}$.

Kolejne listy, zawarte w teczce o sygnaturze F40-185, dotyczą spraw parafii w Tursku Wielkim w województwie sandomierskim. Po niepowodzeniu z ks. Nerlichem, w 1797 r. Jednota Litewska oddelegowała do Małopolski ks. Jana Herowskiego (1744-1826). I tym razem, chociaż ks. Herowski przyjął wokację do zboru w Tursku Wielkim wraz z godnością seniora małopolskiego, i on nie opuścił Wielkiego Księstwa Litewskiego, pozostając w swojej parafii w Ostaszynie w województwie nowogródzkim ${ }^{4}$. Stąd kolejny list Jednoty Małopolskiej z 1798 r. proszący o przyjazd ks. Herowskiego, tym razem do pracy $\mathrm{w}$ zborze $\mathrm{w}$ Piaskach, który także nie przyniósł konkretnych rezultatów.

Chcąc zapewne wynagrodzić małopolskim braciom i siostrom w wierze podwójny zawód, Jednota Litewska zezwoliła w 1799 r., aby wykształcony na jej koszt młody duchowny został skierowany do zboru w Tursku Wielkim. Był nim ordynowany w 1800 r. we Frankfurcie nad Odrą ks. Aleksander Aniszewski (1772-1845). Miał on rodzinne związki z Jednotą Małopolską - jego matką była Katarzyna Metycka (1730-1793), najprawdopodobniej córka konseniora małopolskiego i pastora w Piaskach, ks. Samuela Metyckiego (zm. ok. 1763) i on również urodził się w okolicy Piasków. Jednak i pastor Aniszewski nie pozostał długo w Jednocie Małopolskiej, podążając za patronem generałem Samuelem hr. Ożarowskim (1733-1811) na Litwę w sierpniu $1801 \mathrm{r}^{5}$

Związki pomiędzy Jednotami Małopolską i Litewską (Wielkiego Księstwa Litewskiego) sięgały XVI w. oraz początków polskiej i litewskiej reformacji. Choć oba Kościoły pozostały niezależne od siebie organizacyjnie, wciąż łączyły je bliskie więzy teologiczne i liturgiczne

3 E. Cherner, Stownik biograficzny duchownych ewangelicko-reformowanych: Jednota Litewska i Jednota Wileńska 1815-1939, Warszawa 2017, s. 296-297.

${ }^{4}$ Ibidem, s. 126.

5 Ibidem, s. 40-45. 
- w obu obowiązywała (z drobnymi różnicami) Wielka Agenda Gdańska z 1637 r. Stąd, gdy w 1800 r. Jednota Małopolska znalazła się w głębokim kryzysie personalnym - nie było tam już żadnego seniora lub konseniora duchownego, wysłała ks. Jana Klaudiana do Jamnej (Jamna) w dystrykcie podlaskim Jednoty Wielkiego Księstwa Litewskiego "dla konsekracyi na seniorowstwo" ". Sytuacja powtórzyła się w 1806 r., gdy na godność konseniora Jednoty Małopolskiej Jednota Litewska ordynowała ks. Józefa Kühna (1769-1843). Ponadto oba Kościoły łączyły bliskie kontakty na poziomie towarzyskim i rodzinnym - wielu pastorów Jednoty Litewskiej wywodziło się z rodzin ewangelickich Jednoty Małopolskiej (Bythnerowie, Lutomirscy, Nerlichowie, Stankarowie) czy koleżeńskim, np. nauka w gimnazjum słuckim (bracia Andrzej i Samuel Skierscy), wspólne studia na zagranicznych uczelniach etc.

U progu XIX w. licząca nie więcej niż około 500 wiernych i składająca się formalnie z ośmiu parafii Jednota Małopolska miała już dawno za sobą czasy świetności, kiedy kierowała wielu duchownych do bratniego Kościoła w Wielkim Księstwie Litewskim7 ${ }^{7}$ Teraz to ona pozyskiwała brakujących kaznodziei w Jednocie Litewskiej, korzystała ze stypendiów dla kształcącej się młodzieży w gimnazjum słuckim, a także na uczelniach zagranicznych. I to właśnie tego okresu dotyczą zamieszczone poniżej listy.

Trzeba jednak pamiętać, że przenosiny duchownych reformowanych z Jednoty Litewskiej do Jednoty Małopolskiej zdarzały się już pod koniec XVII w. Jednym z pierwszych był Jan Bythner, kaznodzieja języka polskiego i niemieckiego zboru wileńskiego. Zważając na trudną sytuację kadrową zborów małopolskich, synod Jednoty Wielkiego Księstwa Litewskiego w 1681 r. odpowiedział pozytywnie na prośbę dystryktu lubelskiego Jednoty Małopolskiej i chorążego lubelskiego Pawła Bogusława Orzechowskiego (ok. 1626-1694), patrona zboru w Bełżycach, zezwalając na wokowanie ks. Bythnera do tego zboru. Kolejnymi duchownymi byli ks. Jan Władysław Kozaryn (zm. 1779) i wspomniany powyżej ks. Samuel Metycki ${ }^{8}$. W 1753 r.,

6 BUW, Synod Ewangelicko-Reformowany (dalej: BUW, SER), sygn. 600, k. 108 (kanon nr 11).

7 Łapczyńska Wola, Piaski Wielkie, Sieczków, Sielec, Szczepanowice, Tursko Wielkie, Wiatowice oraz Wielkanoc.

8 BUW, SER, sygn. 600. Pastorska rodzina Bitnerów (Bythnerów) wywodziła się z Małopolski i jedna jej gałąź przeniosła się do Wielkiego Księstwa Litewskiego w połowie XVII w. 
za zgodą synodu Jednoty Wielkiego Księstwa Litewskiego, ks. Kozaryn został wokowany do parafii w Sielcu pod Staszowem, gdzie pracował do $1763 \mathrm{r}$. Wtedy to, w związku z procesem wytoczonym mu przez katolickich duchownych, przeniesiono go do zboru w Piaskach, gdzie osiągnął godność seniora Jednoty Małopolskiej. Jego poprzednikiem w Piaskach był właśnie ks. Metycki, który służył tam od ok. 1758 r. ${ }^{9}$ Jednak u progu XIX w. Jednota Małopolska znajdowała się już w dramatycznej sytuacji kadrowej, o czym świadczą publikowane poniżej listy.

W pierwszym liście ks. Jan Herowski, pastor w Ostaszynie, tłumaczy się wpływowej patronce Joannie Sieheniowej (1768-1846) z porzucenia zamiaru wyjazdu do Małopolski. Choć usprawiedliwia się tutaj swoją chorobą, to trudno nie zauważyć, że jej objawy zbiegły się z czasem wyjazdu. Gdy tylko przeprowadzka stała się niemożliwa do zrealizowania w 1798 r., równie nagle przyszło ozdrowienie pastora, którego dość sarkastycznie życzyła mu adresatka listu. Chcąc się zabezpieczyć przed sugestią przeprowadzki do Małopolski późnym latem, ks. Herowski podaje drugi, dużo bardziej wiarygodny powód: stan zdrowia jego małżonki. W chwili pisania listu jego żona, Ludwika z Okszyckich (1765-1820) była w ciąży, która nie przebiegała najlepiej: urodzona 22 lipca 1798 r. córka Ludwika Wiktoria zmarła zaraz po urodzeniu ${ }^{10}$.

List ten jest też o tyle ciekawy, że pokazuje także, jak niewielkie pole manewru mieli duchowni ewangelicko-reformowani w sprawach kadrowych. Adresatką listu była Joanna z Grabowskich Sieheniowa. Jej siostrą była Marianna z Grabowskich Ożarowska (1772-1846), żona właściciela majątku i patrona zboru w Tursku Wielkim, gen. Samuela Ożarowskiego (1733-1811), dokąd ks. Herowski miał się przenieść. Jak wynika z listu, generałowa Ożarowska przybyła na Litwę w odwiedziny do siostry, gdzie zapewne skarżyła się na niesłowność pastora. Obie siostry były kuzynkami Stefana Ottenhauza (1714-1802), podkomorzego derpskiego (dorpackiego), patrona zboru w Ostaszynie. Ponadto ich siostra stryjeczna Izabela z Grabowskich (1760-1840) była żoną podkomorzego powiatu kobryńskiego Stefana Rayskiego, dyrektora synodu Jednoty

9 W. Kriegseisen Zbór kalwiński w Sielcu koto Staszowa, OiRwP, 35, 1990, s. 165-166; K. Bem, Zarys dziejów zboru ewangelicko-reformowanego w Piaskach Luterskich (Wielkich), s. 93.

10 E. Cherner, op. cit., s. 127. 
Litewskiej, który miał w 1799 r. zadecydować ostatecznie w sprawie wyjazdu ks. Herowskiego do Małopolski oraz - ewentualnie - zastosować kary kościelne w przypadku nieposłuszeństwa. Skłócenie z tak ważną i ustosunkowaną rodziną ewangelicką mogło mieć dla pastora bardzo nieprzyjemne konsekwencje. Swoim niezwykle czołobitnym listem ks. Herowski chyba ułagodził patronkę i rodzinę Grabowskich. Jak wspomniano, w 1799 r. do Małopolski wysłano nie jego, a ks. Aleksandra Aniszewskiego, a on sam pozostał pastorem w Ostaszynie aż do śmierci w 1826 r., zostając nawet w 1813 r. konseniorem zaniemeńskim ${ }^{11}$.

List nr 2 jest $\mathrm{z}$ jednej strony przejawem frustracji seniorów Jednoty Małopolskiej z powodu bezskutecznych zabiegów o duchownego, a z drugiej ewidentnym wyrazem zaniepokojenia o przyszłość Kościoła. U progu 1799 r. pracowało tam już tylko pięciu starszych duchownych, prawie wszyscy w wieku około 60 lat, wakowały urzędy seniora i konseniora ${ }^{12}$. O tym, że ich obawy nie były nieuzasadnione świadczy fakt, że w ciągu sześciu lat czterech z owych pięciu duchownych zmarło. Zdając sobie sprawę ze swej pozycji suplikanta, seniorzy Jednoty Małopolskiej dyskretnie tylko przypominają braciom i siostrom Jednoty Litewskiej dwie wcześniejsze, nieudane próby przysłania im duchownego.

W trzecim liście Jednota niechętnie uwalnia ze służby pastora Adama Huyssona (Huissona) (ok. 1760-1814) z Piasków, który samowolnie wrócił na Litwę, prosząc tylko, aby Jednota Litewska nie pozwoliła mu oczerniać byłych pracodawców. Z treści listu zdaje się wynikać obawa, że może to zniechęcić innych duchownych rozważających podjęcie pracy w małopolskich zborach. Jednota Małopolska sugeruje też, bez wchodzenia w szczegóły, że pozwoliła ks. Huyssonowi na posługę pomimo pewnych ujemnych cech jego charakteru. Opublikowany niżej list jest dużo łagodniejszy w tonie niż kanon nr 8 synodu Jednoty Małopolskiej z 1806 r., w którym stwierdzono dobitnie: „Z powodu wyjazdu Jego Mości Księdza Huissona i opuszczenia kościoła piaseckiego bez poprzedzającego uwiadomienia zwierzchników Jednoty naszej, my zgromadzone stany czując jak się należy

11 Ibidem, s. 126; S. Konarski, Szlachta kalwińska w Polsce, Warszawa 1936, s. 228.

12 Byli nimi: Samuel Głowacki (zm. 1800) w Piaskach, Jan Daniel Klaudian (zm. 1803) w Sielcu, Jan Fryderyk Mozes (zm. 1810) w Sieczkowie, Jakub Fryderyk Teichmann (ok. 1740-1805) w Szczepanowicach oraz Gottlieb Lebrecht Teichmann (zm. 1803) w Wielkanocy. Z nich tylko ks. Głowacki miał ok. 40 lat, ale musiał być już ciężko chory i zmarł na początku 1800 r. 
nieprzyzwoitość tego postępku obowiązujemy Wielmożnego Dyrektora niniejszej kongregacyi, aby napisał list do Prześwietnego Synodu Prowincyi Litewskiej z wytłumaczeniem wszystkich tego wydarzenia okoliczności"13.

Między wierszami władze Jednoty Małopolskiej przyznawały jednak, że warunki materialne pracy ks. Huyssona były rzeczywiście ciężkie, a władze kościelne nie umiały (lub nie mogły) zapewnić mu szybkiej ich poprawy ${ }^{14}$. O tym, że z okoliczności jego wyjazdu wyciągnięto wnioski świadczy kanon nr 3 małopolskiego synodu uchwalony w 1806 r., który wyraźnie oznaczał „potrzeby i wygody życia naszych duchownych" na minimalnym poziomie $1760 \mathrm{złp}^{15}$.

W czwartym liście władze Jednoty Małopolskiej wyraźnie stwierdzały, że w 1806 r. w całym małopolskim Kościele ewangelicko-reformowanym pracował tylko jeden pastor - senior Jan Fryderyk Mozes (zm. 1810) - coraz bardziej podupadający na zdrowiu. Małopolanie prosili więc o udzielenie zgody na przyjazd ks. Józefa Kühna. Z listów i kanonów małopolskich synodów wynika jednoznacznie, że podjął on już wcześniej decyzję o przeprowadzce do Małopolski, a tamtejsza Jednota w kanonie nr 5 z 1806 r. określiła wyraźnie jego wokację jako pastora kierowanego do zboru w Szczepanowicach koło Tarnowa. Jednocześnie powierzono mu opiekę nad wiernymi w wakujących zborach w Wiatowicach koło Bochni oraz Wielkanocy pod Krakowem ${ }^{16}$. Oszczędna zazwyczaj Jednota Małopolska zgodziła się nawet pokryć koszty jego przeprowadzki ze Słucka do Szczepanowic.

Publikowany niżej list nr 4 jest realizacją kanonu nr 6 tychże obrad, gdzie stwierdzono: „My na niniejszej kongregacyi zgromadzone stany, chcąc użyć wszystkich sposobów, aby osadzić osierocone kościoły nasze, gdy z powodu doświadczenia spodziewać się nam należy, że prześwietny Synod Prowincyi Litewskiej obmyśli dla nas subiekta zdatne do obsadzenia tychże. Obligujemy Wielmożnego Dyrektora niniejszej kongregacji, aby pisał do prześwietnego Synodu Prowincyi Litewskiej z wyrażeniem prośby o uskutecznienie żądania naszego a w szczególności, aby oświadczył, iż jest najusilniejszą obligacyją naszą, iżby Wielebnemu Jegomości Księdzu Kühnowi dozwolono

13 BUW, SER, sygn. 600, k. 216 (kanon nr 8).

14 Świadczy o tym kanon nr 10, w którym Jednota przyznaje, że patron Jan Suchodolski od lat, może nawet od początku posługi ks. Huissona, nie wypłacał należnej pastorowi prowizji; ibidem, k. 216.

15 Ibidem, k. 210.

16 Ibidem, k. 211-212. 
było przyjąć wokacyję, którą na niniejszej kongregacyi ułożoną temuż przesyłamy" 17 .

List $\mathrm{nr} 4$ znalazł się w materiałach dotyczących kościoła w Piaskach, gdyż w 1809 r. ks. Kühn z nieznanych powodów opuścił Szczepanowice i podjął pracę w Piaskach Luterskich (Wielkich), gdzie wytrwał do wiosny 1810 r., kiedy to ostatecznie opuścił Małopolskę i powrócił na Litwę. Listy nr 1 i 2 zapewne trafiły do archiwum Jednoty Litewskiej, gdy ks. Aleksander Aniszewski w 1801 r. opuścił Tursko Wielkie i powrócił na Litwę.

Przeprowadzka w 1806 r. ks. Józefa Kühna ze Słucka oraz ordynowanie na pastora Samuela Skierskiego (1781-1844) na chwilę poprawiły sytuację kadrową Jednoty Małopolskiej. Uległa ona ponownemu pogorszeniu, gdy w 1810 r. senior Mozes zmarł, konsenior Kühn powrócił na Litwę, przed powrotem ordynując na pastora ks. Andrzeja Skierskiego (1785-1856). Jednota Małopolska pozostała bez konseniora do 1819 r., a bez seniora aż do 1835 r. ${ }^{18}$

Warto zastanowić się nad motywacjami duchownych Jednoty Litewskiej, którzy akceptowali propozycje objęcia parafii małopolskich ${ }^{19}$. Najczęściej były to powody ambicjonalne, chęć samodzielnej pracy, połączona z względnie szybkim osiągnięciem godności seniora bądź konseniora, na co trzeba było zdecydowanie dłużej czekać na Litwie. I tak w 1806 r. ks. Kühn był w Słucku czwartym i najmłodszym pastorem, bez widoków na szybki awans w hierarchii kościelnej. Przenosiny do Małopolski zapewniły mu nie tylko dobrze opłacaną pracę w zborze w Szczepanowicach koło Tarnowa, z nową i dobrze utrzymaną plebanią, ale i natychmiastowy awans do godności konseniora. Pastor Kühn po powrocie w 1810 r. do Jednoty Litewskiej musiał czekać na taki sam awans aż do 1825 r., kiedy to został konseniorem grodzieńskim. Istotnym elementem była także nadzieja na poprawę kondycji materialnej, zwłaszcza kiedy młody duchowny musiał spłacać długi zaciągnięte w okresie studiów. Tu dobrym przykładem jest ks. Samuel Nerlich, który deklarował gotowość wyjazdu na „miejsce by najdalsze”. Jak wynika umieszczonego tu listu, czasami

17 Ibidem, k. 215.

18 K. Bem, Stownik biograficzny duchownych ewangelicko-reformowanych. Pastorzy $i$ diakonisy Jednoty Matopolskiej i Jednoty Warszawskiej 1815-1939, Warszawa 2015, s. 142-143, 200-202, 210-211.

19 Pastorzy wokowani do zborów małopolskich: ks. Jan Bythner, ks. Samuel Metycki, ks. Jan Władysław Kozaryn, ks. Samuel Nerlich, ks. Jan Herowski, ks. Stefan Kołysza, ks. Adam Huisson, ks. Józef Kühn. 
to duchowni Jednoty Litewskiej podejmowali w sprawie zatrudnienia prywatne rozmowy z Jednotą Małopolską, nie czekając na formalną zgodę władz Jednoty Litewskiej.

List nr 3 pozwala także sprostować dane biograficzne podane w artykule o Piaskach Luterskich sprzed dwudziestu lat, dotyczące mało znanego pastora Huyssona ${ }^{20}$. Adam Huysson (Huisson) (ok. 1760-1814) studiował w Królewcu od 1780 r., a od 1782 r. na uniwersytecie w Marburgu. Po powrocie ze studiów ordynowano go na diakona na synodzie Jednoty Litewskiej w 1786 r. i skierowano do Zabłudowa, gdzie ordynowano go na stopień pastora. Pomagał słabnącemu seniorowi podlaskiemu ks. Beniaminowi Kanottowi (zm. 1790) jeszcze w 1790 r. Potem, do 1800 r., był pastorem w Sidrze na Podlasiu, która po trzecim rozbiorze Rzeczypospolitej w 1795 r. znalazła się w Prusach Nowowschodnich (Neuostpreussen). W 1800 r. został przeniesiony przez synod na stanowisko drugiego kaznodziei do Birż. Nie zajmował go jednak długo, już w 1802 r. występuje bowiem jako pastor w Piaskach Luterskich (Wielkich). Również i tam nie zagrzał długo miejsca - opuścił tę parafię samowolnie na początku 1806 r., w każdym razie przed kwietniem tego roku, kiedy datowany jest trzeci z publikowanych niżej listów. Na synodzie Jednoty Litewskiej w czerwcu 1806 r. wyznaczono go na pastora w Nowym Mieście koło Poniewieża jako „powrócić mającego z Galicyi”. Ks. Huysson był potem w latach 1806-1811 wymieniany jako kaznodzieja w Nowym Mieście, a ponadto w latach 1808-1810 jako kaznodzieja w Bielicy k. Lidy. Zmarł 8 września 1814 r. w Bielicy.

Warto na koniec zauważyć, że za wyjątkiem ks. Huyssona wszyscy inni duchowni Jednoty Litewskiej, którzy u schyłku XVIII i na początku XIX w. podjęli pracę w Jednocie Małopolskiej, by potem z niej samowolnie zrezygnować (Aniszewski, Herowski, Kühn, Nerlich), zrobili potem kariery duchowne w Jednocie Litewskiej. Uniknięcie konsekwencji samowolnego opuszczenia powierzonych sobie zborów i wiernych było zapewne możliwe dzięki powszechnej wiedzy o tym, jak trudne warunki pracy duszpasterskiej panowały w wymierającej i upadającej Jednocie Małopolskiej, która uległa ostatecznie rozwiązaniu w 1849 r. Jej ostatnia parafia w Sielcu przetrwała do 1939 r., ale już w składzie tzw. Jednoty Warszawskiej, a następnie (po 1918 r.) Kościoła Ewangelicko-Reformowanego w Rzeczypospolitej

20 K. Bem, Zarys dziejów zboru ewangelicko-reformowanego w Piaskach Luterskich (Wielkich), s. 95. 
Polskiej. Przykład ks. Huyssona, który kariery nie zrobił nawet po powrocie na Litwę, zdaje się potwierdzać zastrzeżenia pod jego adresem wspomniane przez Małopolan.

Listy nr 3 i 4 powstały w trakcie obrad synodu Jednoty Małopolskiej - zwanej wtedy oficjalnie Synodem Obydwóch Galicyi ${ }^{21}$ - który od 6 do 8 kwietnia 1806 r. obradował w Grzymale (Sieczkowie), w tamtejszym kościele ewangelicko-reformowanym (kalwińskim $)^{22}$. W imieniu Małopolan pisał je dyrektor synodu, Rafał Konarski ${ }^{23}$. Należy też zwrócić uwagę, że w 1806 r. przenosiny między obu Kościołami były prawdziwymi podróżami za granicę. Zbory małopolskie znajdowały się bowiem na terenie należącej do Austrii Galicji, podczas gdy większość zborów litewskich znalazła się na obszarze Cesarstwa Rosyjskiego.

\section{Listy}

\section{$\mathrm{Nr} 1$}

Ks. Jan Herowski do Joanny z Grabowskich Sieheniowej ${ }^{24}$ w sprawie jego misji w Tursku Wielkim, dobrach Ożarowskich, Ostaszyn, 8 maja $1798 \mathrm{r}$.

Dnia 8 maja 1798 w Ostaszynie

Wielmożna Mości Dobrodziko!

Bardzo żałuję, że szacowny Wielmożnej Wielce Miłościwej Pani Dobrodziki bilet z Janopola d. 14 kwietnia datowany, nie pierwej, aż dziś dopiero mię doszedł; bo gdybym go był dawniej odebrał, i był uwiadomiony o pewnym Jaśnie Wielmożnej Jejmości Pani

21 W latach 1798-1800 Jednota Małopolska nosiła oficjalnie nazwę Kongregacji lub Synodu Prowincji Zachodniej Galicji (BUW, SER, sygn. 600, k. 177-180), a następnie od 1801 r. Synodu Obydwóch Galicyi (ibidem, k. 187).

22 Ibidem, k. 210.

23 Rafał Konarski (1749-1830) - syn Jana (zm. 1763) stolnika mozyrskiego i Wiktorii z Estków (zm. 1788), występujący z tytułem szambelana, dyrektor synodów Jednoty Małopolskiej w 1802, 1804, 1806, 1807 i 1811 r., w latach 1815-1830 jej senior świecki.

24 Joanna z Grabowskich (1768-1846) - córka Tomasza Mariana (1715-1771) i jego drugiej żony Doroty z Ottenhauzów (1744-1830), wyszła za mąż w $1791 \mathrm{r}$. za katolika Ignacego Siehenia (zm. 5 V 1834). 
Generałowej Ożarowskiej ${ }^{25}$ Dobrodziki do Litwy przybyciu, starałbym się koniecznie zbiec do Szerszewa, dla umówienia się ostatecznego, i postanowienia co pewnego względem wokacyi mojej do Turska. Teraz zaś nie możną już to wcale dla mnie jest rzeczą, kiedy rozpocząłem kuracyję majową, dla zasilenia cokolwiek zdrowia; bo od marca nie byłem, i nie jestem zupełnie zdrowy. Powinszowanie jednak Wielmożnej Wielce Miłościwej Pani Dobrodziki powrotu do zdrowia, łaskawie mnie oświadczone, z najczulszą wdzięcznością jako dowód łaski pańskiej ku mnie, przyjmuję, i najpokorniejszą u nóg Wielce Miłościwej Pani Dobrodziki składam za nie podziękę.

Co do interesu wokacyi mojej do Turska, tak się oświadczam. Gdy $\mathrm{z}$ różnych przyczyn i powodów, fatalnych dla mnie, dotąd w prowincyi litewskiej znajduję się, i nie będę mógł, stosownie do okoliczności moich, choćbym najbardziej chciał, opuścić onej przed następnym Synodem Litewskim; więc determinowałem zdać się zupełnie na decyzyję tegoż Synodu i, nie prosząc, ani o przyjęcie mnie znowu do usług Jednoty Litewskiej, na fundamencie zabezpieczonego mi, Kanonem Synodu ostatniego regresu; ani o potwierdzenie, czyli ponowienie misyi przeszłorocznej do Polski; czekać w Ostaszynie dyspozycyi synodowej, która, jeżeli będzie potwierdzeniem przeszłorocznej, wraz, bez najmniejszej już zwłoki, wyjadę z Litwy. Byleby tylko szczęśliwie odbyła spodziewaną w lipcu chorobę swoją żonka moja ${ }^{26}$, która tej odmianie nie tylko nie jest przeciwna, ale owszem całkiem jest za nią. Że się do Synodu Litewskiego referuję, i na Jego decyzję znowu się oddaję, czynię to i dla tego, iż się jeszcze w tej prowincyi znajduję, a oddalić się z niej w następnych dwóch miesiącach nie mogę, i z innych ważnych bardzo dla mnie przyczyn, z przedłożeniem których nie rozwodząc się tu, będę miał honor ustnie, kiedy opowiedzieć się. Spodziewam się jednak, że Synod zechce potwierdzić przeszłoroczną misyję, kiedy jak mam wiadomość z Wilna, jest jakaś nadzieja, że dyrektorem będzie znowu Jaśnie Wielmożny podkomorzy kobryński ${ }^{27}$.

25 Marianna Elżbieta z Grabowskich (1772-1846) - siostra Joanny, wyszła za mąż w 1791 r. za kuzyna i współwyznawcę, gen. Samuela Ożarowskiego (zob. przyp. 28).

26 Druga żona Herowskiego, Ludwika Bogumiła z Okszyckich, była w momencie pisania listu w ciąży. Urodzona 22 VII 1798 r. córka Ludwika Wiktoria zmarła w dniu urodzenia.

27 Prawdopodobnie chodzi o Stefana Rayskiego (1748-1813), żonatego od 1783 r. z Izabelą z Grabowskich (1760-1840), siostrą stryjeczną Joanny Sieheniowej i Marcjanny Ożarowskiej. 
To jest moje szczere, ostateczne i nieodmienne oświadczenie. Jeśliby zaś Jaśnie Wielmożni Ichmościowie Państwo kolatorowie turscy Dobrodziejstwo albo już mieli innego księdza, nie przyczekawszy mię, albo innego mieć chcieli, proszę najpokorniej i najgoręcej Wielmożnej Wielce Miłościwej Pani Dobrodziki o tę łaskę, abym był jakimkolwiek sposobem, przed następnym Synodem litewskim, o tym uwiadomiony.

Upadam, wraz z żonką, do nóg najszanowniejszego dla nas Państwa Dobrodziejstwa i mam honor pisać się z powinną czcią, Wielmożnej Wielce Miłościwej Pani Dobrodziki najobowiązańszym i najniższym sługą

Ks. J[an] Herowski

\section{$\mathrm{Nr} 2$}

Seniorowie Jednoty Małopolskiej Samuel Ożarowski i Jan Malicki do władz Jednoty Litewskiej w sprawie delegowania do Małopolski duchownego, Tursko, 10 maja 1799 r.

Jaśnie Wielmożni, Wielmożni, Przewielebni, Wielebni nam Wielce Miłościwi

Panowie i Dobrodzieje!

Kiedy po dwakroć powtórzona dyspozycyja Świątobliwego Synodu Jaśnie Wielmożnych, Wielmożnych, Przewielebnych, Wielebnych, Wielce Wielmożnych Miłościwych Panów Dobrodziejów dotąd nie jest dopełniona, śpieszymy znowu z niniejszą odezwą naszą nie w celu zaniesienia uskarżeń a tym mniej obwinienia kogo, bo nie przystoi nam wchodzić w przyczyny tak nadzwyczajnego między zwierzchnością a subordynowaną osobą wypadku, ale jako suplikanci, którym wolno nie przestawać kołatać do dobroczynnych serc Jaśnie Wielmożnych, Wielmożnych, Przewielebnych, Wielebnych, Wielce Wielmożnych Miłościwych Panów Dobrodziejów, żebyście pobudzeni gorliwością, o utrzymanie chwały Bożej w stronach gasnącego już światła Ewangelii, zaczęte dzieło okazania nam prawdziwie chrześcijańskiej miłości, uskutecznić raczyli.

Nie chcemy zatrudniać Świątobliwego Synodu obszernym opisaniem najokropniejszego stanu, w jakim się zgromadzenia nasze znajdują. Ogołocone z pasterzów nie słyszą Słowa Bożego, a z trudnością niejednej familii przychodzi partycypować w administracyi Sakramentów Św. Słowem dopełniło się ad litteram rozgniewanie Boskie nad nami dla niewdzięczności ojców naszych i nas samych, że głód Słowa Bożego in extenso na nas rozciągniony. Wszelkie nasze usilności 
i starania, żeby zapobieżeć tej najsroższej pladze były daremne: ale jeżeli Bóg litościwy nie zechce do szczętu świecznika swego dogasić w tej ojczyźnie naszej i wzbudzi politowanie i żarliwość w łaskawych zawsze od dawna sercach Jaśnie Wielmożnych Wielmożnych Przewielebnych Wielebnych Panów Dobrodziejów, że nam użyczycie takowe subiectum, które by zdatne było nie tylko opiekować się jednym zgromadzeniem, ale całej Jednocie przodować w gorliwości, tak nauką jak i przykładnością, ile że pierwsze miejsce dla przybyć mającego jest destynowane. Za opatrzenie dostateczne, poważanie i szanowanie tak żądanej i nieuchronnie potrzebnej osoby cała Jednota nasza uroczyście zaręcza. My zaś oczekując z ufnością na uskutecznienie po dwakroć udecydowanej dla nas [?]ylednościa; mamy honor zostawać z najpowinniejszym uszanowaniem.

Jaśnie Wielmożnych, Wielmożnych, Przewielebnych, Wielebnych nam wielce miłościwych WM Panów Dobrodziejów najniżsi słudzy Samuel Ożarowski ${ }^{28}$ Senior [Ego Ord ${ }^{\mathrm{b}}$ ] i pierwszy Kurator Jan na Malicach Malicki ${ }^{29}$ Senior [Eq Proic ${ }^{\mathrm{c}}$ ]

Z Turska, 10 maja 1799

\section{$\mathrm{Nr} 3$}

Rafał Jaxa Konarski, dyrektor synodu Jednoty Małopolskiej, do władz Jednoty Litewskiej w sprawie pastora Adama Huyssona, Grzymała, 6 kwietnia 1806 r.

Jaśnie Wielmożni i Wielmożni Mości Dobrodzieje!

Ponieważ Wielebny Jegomość Ksiąadz Huison, przybywszy kosztem komunitety do tego Kraju, objął plebaniją, przy kościele piaseckim,

a Tekst uszkodzony.

b Skrót nieczytelny, najprawdopodobniej: Equ[estri] Ord[ine], tzn. senior świecki.

c Skrót nieczytelny, najprawdopodobniej: Equ[estri] Ord[ine], tzn. senior świecki.

28 Samuel Ożarowski (1733-1811) - syn Bogusława i Heleny z Orzechowskich (zm. 1784), do 1801 r. właściciel majątku i patron zboru w Tursku Wielkim, w latach 1782-1801 senior i 1798-1801 kurator Jednoty Małopolskiej. Po przeprowadzce w $1801 \mathrm{r}$. na Litwę fundator razem z żoną i patron zboru w Raśnej. Jego drugą żoną była Marianna Elżbieta z Grabowskich (zob. przyp. 25).

29 Jan Malicki (1727-1804) - syn Andrzeja (zm. 1732) i Heleny z Dunin-Karwickich, pułkownik, w latach 1775-1803 senior świecki Jednoty Małopolskiej - ostatni z rodu. 
zaczął pełnić obowiązki przyjętego na siebie urzędu, w następnym zaś czasie prezentując się na Synodach naszych, tym samym okazał chęć poddania się zupełnie pod prawa zwierzchności tej Jednoty, której dobrowolnie podobało się onemuż zostać członkiem. Gdy później zostając $\mathrm{w}$ jednostajnym przekonaniu przez lat kilka potwierdzał to w każdej swojej czynności, że będąc płatnym od komunitety naszej, powinien był dopełnić przyłączone do stanu swojego obowiązki. Wnieść stąd należy jak w wielkim Jednotę naszą zostawił podziwieniu, gdy się dowiedziała że Wielebny Jegomość Ksiądz Huison, bez poprzedzającej do swoich zwierzchników referencyi, opuścił sobie powierzony Kościół i wyjechał z kraju. Jednota nasza nie spodziewa się żeby Wielebny Jegomość Ksiądz Huison, popełniwszy tak nieprzyzwoitą zdrożność mógł ją jeszcze połączyć z kalumniji przestępstwami. Atoli chcąc usprawiedliwić swoje względem niego postępowanie ma za powinność donieść Prześwietnemu Synodowi Prowincyi Litewskiej, iż w niczym najmniejszego do podobnych kroków z swojej strony nie dała mu powodu. Odbierał zawsze wszystko, co rocznie odbierać był powinien, ostatnich zaś czasów, gdy się uskarżał, iż mu jego nie wystarcza pensyja, miał sobie ofiarowane złotych polskich dwieście. Mimo tych darów i ze wzgardą uczynionych nadziei, które z czasem koniecznie stan jego ulepszyć mogłyby, oddalił się, osirocił Kościół, i zgromadzenie, które do żadnej względem niego nie czuje się winy ${ }^{30}$.

Gdyby na ostatek Wielebny Jegomość Ksiądz Huison i miał prawo jakie żalić się przeciwko komu, należało się zaskarżyć go i czekać przyzwoitej na uczynione zażalenia swoje sprawiedliwości, lecz tego niezrobiwszy, traci moc swoją to wszystko, co w tej okoliczności za sobą powiedzić mógłby.

Jednota nasza niechcąc szkodzić Wielebnemu Jegomości Księdzu Huisonowi zamilcza i puszcza w niepamięć to wszystko, coby mogła ze swojej strony przeciwko niemu wnosić, tego tylko żąda, aby bezstronną sam sobie oddając sprawiedliwość oddał ją potem Jednocie naszej.

Te przełożenia z zlecenia i imieniem Jednoty naszej Prześwietnemu Synodowi Litewskiemu uczyniwszy wyznaję żem jest z powinnym

30 Jednota Małopolska przedstawia tutaj nieco zbyt optymistyczny obraz warunków materialnych w Piaskach Wielkich. Przeprowadzana w 1804 r. wizytacja tejże parafii przedstawia dość przygnębiający obraz; zob. BUW, SER, sygn. 809 oraz jej streszczenie w K. Bem, Zarys dziejów zboru ewangelicko-reformowanego w Piaskach Luterskich (Wielkich), s. 95-96. 
uszanowaniem Jaśnie Wielmożnych i Wielmożnych Waszmościów Panów Dobrodziejów najniższy sługa

Rafał Jaxa Konarski niniejszej kongregacyi dyrektor

Grzymała, dnia 7 Aprilis 1806 roku

\section{$\mathrm{Nr} 4$}

Rafał Jaxa Konarski, dyrektor synodu Jednoty Małopolskiej, do władz Jednoty Litewskiej w sprawie zgody na wokację do Małopolski pastora Józefa Kühna, Grzymała, 7 kwietnia 1806 r.

Jaśnie Wielmożni i Wielmożni Mości Dobrodzieje!

Zwrócona uwaga Jednoty naszej na przeszłe lata ciąłe nam przedstawia wydarzenia, że Prześwietny Synod Prowincyi Litewskiej liczne dawał jej dowody dobroci swojej, dozwalając duchownym osobom od swego zwierzchnictwa dependującym, obejmować wakujące przy kościołach naszych miejsca. Takowa uczynność będąc skutkiem jak gorliwego o rozszerzenie Chwały Boskiej Ducha, tak przyjaznej dla nas chęci, czyni zawsze w sercach naszych wrażenie, które dzieło równie szlachetne jak cnotliwe tworzyć ma prawo.

Miłym dla naszej wdzięczności jest obowiązkiem, ponawiać to ustawicznie, jak wysoce ceniemy te względy. Lecz jeżeli kiedy potrzebna Jednocie naszej była w tym rodzaju Prześwietnego Synodu Prowincyi Litewskiej pomoc, teraz staje się tym naglejszą. Osierocone po utraconych pasterzach kościoły najsmutniejszego ich stanu wystawiają widok. Losem przeciwnym do tego przyszliśmy nieszczęścia, że jednego tylko mamy księdza, który w tutejszych zgromadzeniach wszystkie duchowne zastępuje prace ${ }^{31}$. Jednota nasza zostając $\mathrm{w}$ tak przykrym położeniu, udaje się do Prześwietnego Prowincyi Litewskiej Synodu i przedkłada swoje żądania, aby raczył obmyślić subiekta któreby w kraju naszym duchowną przy osieroconych kościołach dla Jednoty naszej mogli pełnić posługę.

Nim to będzie mogło być wykonanym, teraz sądziemy za najpierwszą dla nas powinność, referować się do Prześwietnego Synodu Litewskiego, z przełożeniem onemuż najusilniejszej naszej prośby, aby Wielebny Jegomość Ksiądz Kühn, który oświadczył już nam chęć swoją,

31 Był nim coraz słabszy na zdrowiu ks. Fryderyk Mozes (zm. 1810) z parafii w Sielcu. 
mógł zostać od obowiązków uwolnionym i aby mu łaskawie dozwolono było przyjąć od nas wokacyją.

Czułość serca pięknie myślących wszystkich Prześwietnego Synodu Litewskiego członków, zaręcza nam, iż obejmując w całej swojej rozległości smutny stan położenia naszego, nie zechce nam odmówić tego o co prosimy. Zwykła ich dla nas dobroć podając nam w tej okoliczności przyjacielską pomoc, najdroższą tę dla swego wspaniałego umysłu zapewni satysfakcyją, która w szczęściu drugich własnego szuka ukontentowania.

Te imieniem całej Jednoty i za jej zleceniem Prześwietnemu Synodowi Prowincyi Litewskiej uczyniwszy przełożenia, mam honor wyznać, że jestem z najprzyzwoitszym uszanowaniem Jaśnie Wielmożnych i Wielmożnych Waszmościów Panów Dobrodziejów najniższy sługa

Rafał Jaxa Konarski niniejszej kongregacyi dyrektor

Grzymała, dnia 7 Aprilis 1806 roku

\title{
Bibliografia
}

\author{
Źródła archiwalne
}

Lietuvos mokslų akademijos Vrublevskių biblioteka (Biblioteka im. Wróblewskich Litewskiej Akademii Nauk w Wilnie), Synod Kościoła Ewangelicko-Reformowanego, sygn. F40-190

Biblioteka Uniwersytecka w Warszawie, Synod Ewangelicko-Reformowany, sygn. 600,809

\section{Opracowania}

Bem K., Stownik biograficzny duchownych ewangelicko-reformowanych. Pastorzy i diakonisy Jednoty Matopolskiej i Jednoty Warszawskiej 1815-1939, Warszawa 2015

Bem K., Zarys dziejów zboru ewangelicko-reformowanego w Piaskach Luterskich (Wielkich) koto Lublina: 1563-1649-1849, OiRwP, 43, 1999, s. $85-98$

Cherner E., Stownik biograficzny duchownych ewangelicko-reformowanych: Jednota Litewska i Jednota Wileńska 1815-1939, Warszawa 2017

Kłaczewski W., Zbory różnowiercze w Piaskach $i$ ich patronowie, „Rocznik Lubelski”, 21, 1979, s. 65-75

Konarski S., Szlachta kalwińska w Polsce, Warszawa 1936 
Kriegseisen W., Ewangelicy polscy i litewscy w epoce saskiej (1696-1763). Sytuacja prawa, organizacja i stosunki międzywyznaniowe, Warszawa 1996 Kriegseisen W., Zbór kalwiński w Sielcu koto Staszowa, OiRwP, 35, 1990, s. $157-178$

\section{Contribution to the History of the Evangelical Reformed Congregations at Piaski Luterskie (Wielkie) near Lublin and Tursko Wielkie, and the Contacts between the Calvinist Unities of Lesser Poland and Lithuania at the Turn of the Nineteenth Century}

The article presents four, previously unknown letters, found in the Library of the Lithuanian Academy of Sciences, Vilnius, about the Calvinist congregations at Piaski Wielkie near Lublin, and Tursko Wielkie, both in Lesser Poland. They complement information about three pastors associated with these congregations: Jan Herowski (1744-1826), Adam Huisson (c. 1760-1814), and Józef Kühn (1769-1843) - all hailing from the Lithuanian Reformed Church.

While brief, these documents are evidence of the problems faced by the Lesser Poland Reformed Unity (Church) in the early nineteenth century, with only one pastor in active service. Clergy transfers from Lithuania, dating back to the eighteenth century, helped the once-mighty, and now struggling Lesser Poland Unity to continue to exist and function as a Church. It should be observed that none of these early nineteenth-century transfers was permanent (unlike their predecessors in the eighteenth century), and all the clergymen returned to Lithuania to serve there.

Secondly, the letters demonstrate that even after the 1795 partition of Poland, and even though both synods found themselves separated by international borders - the Unity of Lesser Poland (formally in Austria) and of Lithuania (formally in Russia) continued to maintain close institutional, theological, and personal ties, with minimal interference from the official authorities.

Ewa Cherner - Paryż, zainteresowania: kalwińska Jednota Litewska od XVII do XX w.

Ewa Cherner - Paris, research interests: Calvinist Lithuanian Unity from the $17^{\text {th }}$ to $20^{\text {th }} \mathrm{cc}$.

E-mail: ewa.cherner@gmail.com 
Dr Kazimierz Bem - pastor w First Church in Marlborough (Congregational) UCC w stanie Massachusetts w USA i wykładowca Ewangelikalnej Wyższej Szkoły Teologicznej we Wrocławiu (EWST). Jego zainteresowania badawcze to historia i eklezjologia Kościołów ewangelicko-reformowanych na ziemiach polskich od XVI do XIX w., a także historia kalwinizmu w Europie, Nowej Anglii i na Sri Lance do połowy XIX w.

Kazimierz Bem - PhD (2007), Vrije Universiteit Amsterdam, is pastor of First Church in Marlborough (Congregational) UCC in Massachusetts, USA, and a lecturer at the Evangelical School of Theology (EWST) in Wrocław. He received his M.Div. and S.T.M. degrees from Yale Divinity School in 2010 and 2012. His research areas cover history and ecclesiology of Calvinism in Poland in the $16^{\text {th }}-19^{\text {th }}$ centuries, as well as history of the Reformed movement in Europe, New England, and Sri Lanka until the mid-19 ${ }^{\text {th }}$ century.

E-mail: kazimierz.bem@gmail.com 